\title{
Effect of copper-sulphur bond on the DNA photo-cleavage activity of 2-(methylthio)ethylpyridine-2-carbaldimine copper(II) complexes
}

\author{
TARKESHWAR GUPTA, ASHIS K PATRA, SHANTA DHAR, MUNIRATHINAM NETHAJI \\ and AKHIL R CHAKRAVARTY* \\ Department of Inorganic and Physical Chemistry, Indian Institute of Science, Bangalore 560 012, India \\ e-mail: arc@ipc.iisc.ernet.in
}

\begin{abstract}
The binding and photo-induced DNA cleavage activity of a binary complex $\left[\mathrm{CuL}_{2}\right]\left(\mathrm{ClO}_{4}\right)_{2}$ (1) and the in situ generated ternary complexes $[\mathrm{CuLB}]\left(\mathrm{ClO}_{4}\right)_{2}$ from 1 (B: 1,10-phenanthroline, phen, 2; dipyrido[3,2-d: $2^{\prime}, 3^{\prime}-f$ ] quinoxaline, dpq, 3) are studied, where $\mathrm{L}$ is a $\mathrm{N}_{2} \mathrm{~S}$-donor tridentate Schiff base 2(methylthio)ethylpyridine-2-carbaldimine. Complex 1, structurally characterized by X-ray diffraction study, has six-coordinate meridional geometry showing $\mathrm{CuN}_{4} \mathrm{~S}_{2}$ coordination. The $\mathrm{Cu}-\mathrm{N}$ bond lengths are in the range of $1.968(3)$ to $2 \cdot 158(4) \AA$. The $\mathrm{Cu}-\mathrm{S}$ bond lengths of $2 \cdot 599(2)$ and $2 \cdot 705(2) \AA$ are significantly long indicating weak covalent interaction between copper and sulphur atoms. The thiomethyl groups are cis to each other giving $\mathrm{S}-\mathrm{Cu}-\mathrm{S}$ angle of $75 \cdot 82(5)^{\circ}$. The $\mathrm{Cu}-\mathrm{N}$ (pyridyl) bond distances are longer than the $\mathrm{Cu}-\mathrm{N}(\mathrm{imine})$ bonds. The complexes are redox active and display a quasi-reversible cyclic voltammetric response assignable to the $\mathrm{Cu}(\mathrm{II}) / \mathrm{Cu}(\mathrm{I})$ couple near $0 \cdot 0 \mathrm{~V}$ vs SCE in DMF-Tris buffer $(1: 4 v / v)$ using $0 \cdot 1$ $\mathrm{M} \mathrm{KCl}$ as supporting electrolyte. Electronic spectra of the complexes show a $d-d$ band in the range 630 to $700 \mathrm{~nm}$ in DMF along with higher energy charge transfer bands. While complex $\mathbf{1}$ is a poor binder to DNA, the ternary complexes show good DNA binding propensity. The photo-nuclease activity of 1-3 is studied using UV and visible wavelengths. The DNA cleavage activity at $365 \mathrm{~nm}$ follows the order: $3>2>1$. The cleavage reaction involves the formation of singlet oxygen as the reactive species in a type-II process.
\end{abstract}

Keywords. DNA photo-cleavage; copper(II) complexes; Schiff base; crystal structure; phenanthroline bases.

\section{Introduction}

DNA cleavage activity of transition metal complexes under physiological conditions has gained considerable current interest for varied applications of such complexes in nucleic acids chemistry. ${ }^{1-15}$ DNA can be cleaved by hydrolytic and oxidative pathways. The hydrolytic process involves cleavage of the phosphodiester bond, leading to the formation of fragments that could be religated by enzymatic processes. The oxidative cleavage of DNA involves nucleobase oxidation and/or degradation of sugar by abstraction of deoxyribose hydrogen atom(s). Such cleavage can occur by chemical or photochemical means. The photo-induced oxidative DNA cleavage has advantages in therapeutic applications as only a source of light is used in this process instead of any external additives like reducing or oxidizing agents that are necessary for observing "chemical nuclease" acti-

Dedicated to the memory of the late Professor Bhaskar G Maiya *For correspondence vity. The photo-cleavage of DNA with visible light irradiation is of importance in photodynamic therapy (PDT) of cancer. ${ }^{16-20}$ Photofrin ${ }^{\circledR}$ which is a currently used PDT drug for lung and esophageal cancers is a mixture of hematoporphyrin and its derivatives. This drug is active on laser irradiation at $630 \mathrm{~nm}$ to generate singlet oxygen as the reactive species. Among non-porphyrinic species, DNA-binding and photo-cleavage activities of polypyridyl $4 d$ - and $5 d$ metal complexes are studied in detail. ${ }^{21-26}$ In contrast, the chemistry of copper-based photo-nucleases has remained relatively unexplored. ${ }^{27}$ Copper being a bio-essential element, its complexes find more applications in nucleic acid chemistry as compared to the heavier transition elements.

We have recently shown that non-porphyrinic binary and ternary copper(II) complexes are efficient photocleavers of DNA on UV or visible light irradiation. $^{28-36}$ The ligands or metal salts alone are found to be cleavage-inactive. However, when a photosensitizing ligand and a DNA binder are covalently bonded to a copper(II) centre, the complex becomes 
cleavage-active. Mechanistic studies have revealed that metal-assisted light-induced DNA cleavage involves photo-excitation of the charge transfer and $d-d$ bands. ${ }^{29}$ We have also observed that sulphurcontaining ligands act as photosensitizers and the photosensitizing effect is greater when the sulphur is bound to the metal centre and the concerned moiety lacks $\pi$-conjugation. The choice of sulphur-containing Schiff base ligand is based on the fact that thio or thione moieties are known to show efficient intersystem crossing to the triplet state on photo-irradiation. ${ }^{37-39}$ Excited states with longer lifetimes can cause oxidative damage of DNA directly by a type-I process or can activate molecular oxygen from its stable triplet state $\left({ }^{3} \mathrm{O}_{2}\right)$ to the cytotoxic singlet state $\left({ }^{1} \mathrm{O}_{2}\right)$ in a type-II process. ${ }^{4}$

Design of the metal complex as a photo-cleaver of DNA necessitates the presence of a photosensitizer and a DNA binder. Here, we report the synthesis and crystal structure of a binary complex $\left[\mathrm{CuL}_{2}\right]\left(\mathrm{ClO}_{4}\right)$ (1), with a photosensitizable sulphur-containing tridentate Schiff-base ligand 2-(methylthio)ethylpyridine-2-carbaldimine (L) (scheme 1). To incorporate a DNA binder, we have prepared two ternary complexes of formulation $[\mathrm{CuLB}]\left(\mathrm{ClO}_{4}\right)_{2}$, where $\mathrm{B}$ is a heterocyclic base, viz. 1,10-phenanthroline (phen, 2) and dipyrido[3,2-d : 2',3'-f]quinoxaline (dpq, 3). Copper complexes of phenanthroline bases like phen and dpq are known to bind DNA efficiently..$^{40-42}$ The dpq ligand in $\mathbf{3}$ is a photosensitizer as DNA intercalator quinoxalines are known to cleave DNA at $365 \mathrm{~nm}$ by the photo-excited ${ }^{3}\left(n-\pi^{*}\right)$ and/or ${ }^{3}\left(\pi-\pi^{*}\right)$ states in the absence of any external additives. ${ }^{43}$ The significant result of the present study is the lightinduced DNA cleavage activity of the complexes at $365 \mathrm{~nm}$. The $\mathrm{Cu}-\mathrm{S}$ bond length in $\mathbf{1}$ is found to be an important factor in promoting metal-assisted lightinduced DNA cleavage activity.

\section{Experimental}

\subsection{Materials}

All reagents and chemicals were purchased from commercial sources and used without further purification. Solvents used for electrochemical and spectroscopic studies were purified and dried by standard procedures before use. The supercoiled (SC) pUC19 DNA (caesium chloride purified) was purchased from Bangalore Genie (India). The calf thymus (CT) DNA, agarose (molecular biology grade) and ethidium bromide (EB) were obtained from Sigma. Tris (hydroxymethyl)aminomethane- $\mathrm{HCl}$ (Tris- $\mathrm{HCl}$ ) buffer was prepared using deionized and sonicated triple-distilled water. The ligand $\mathrm{L}$ was prepared by

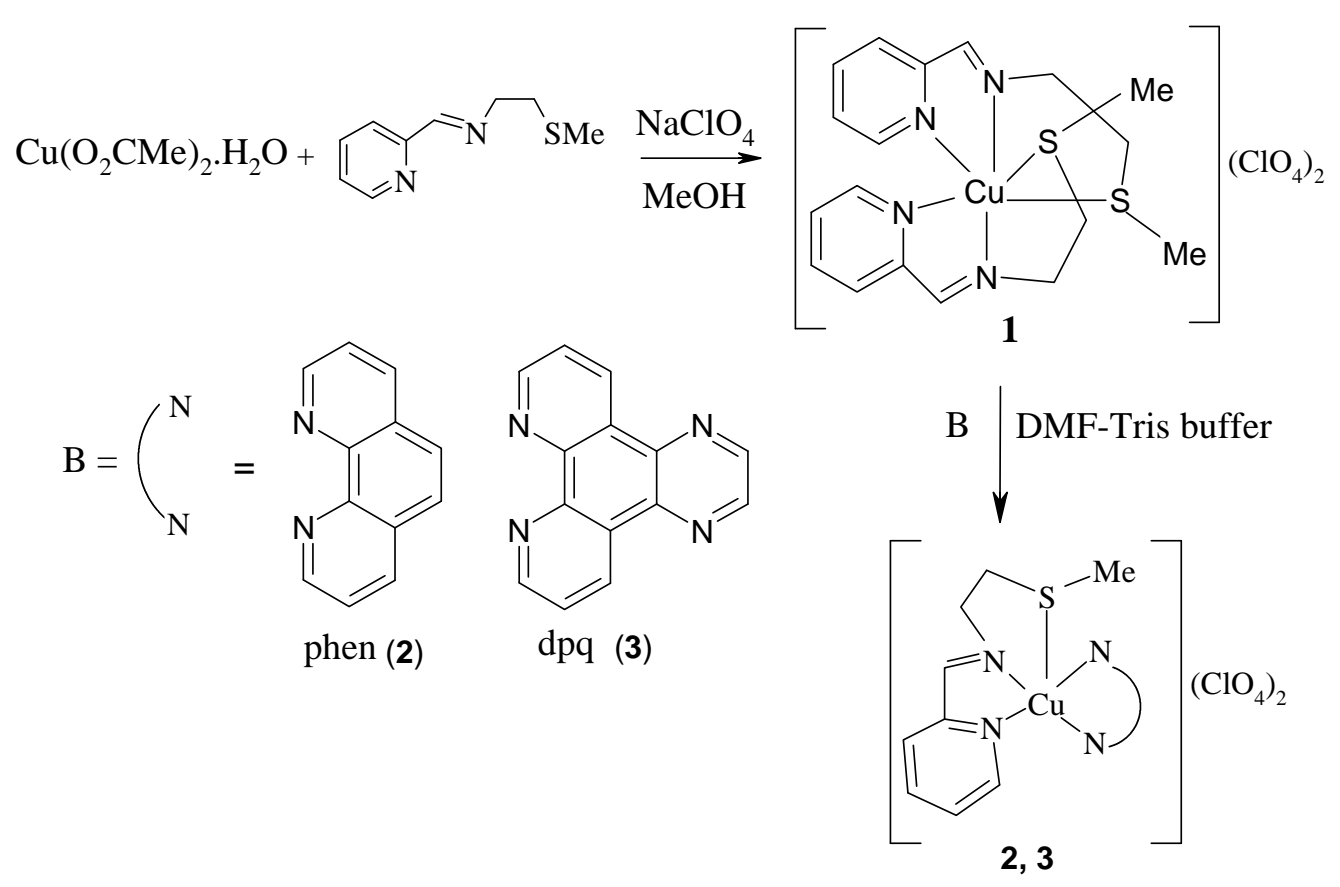

Scheme 1. The reaction pathways for the synthesis of the binary complex $\left[\mathrm{CuL}_{2}\right]\left(\mathrm{ClO}_{4}\right)_{2}$ (1) and in situ generation of the ternary complexes $[\mathrm{CuLB}]\left(\mathrm{ClO}_{4}\right)_{2}(\mathrm{~B}$ : phen, 2; dpq, 3). 
Schiff-base condensation using pyridine-2-carboxaldehyde and 2-mercaptoethylamine followed by methylation with methyliodide in presence of sodium methoxide. Dipyrido[3,2- $d: 2^{\prime}, 3^{\prime}-f$ ] quinoxaline (dpq) was prepared by a literature procedure. ${ }^{44}$

\subsection{Physical measurements}

Elemental analysis was performed using a Thermo Finnigan Flash EA 1112 CHNSO analyser. Infrared and electronic spectra were recorded on Perkin-Elmer Spectrum One and Perkin-Elmer Lambda 35 spectrophotometers respectively. Molar conductivity measurements were made using a Control Dynamics (India) conductivity-meter. Electrochemical measurements were carried out at $25^{\circ} \mathrm{C}$ on an EG\&G PAR model 253 Versa Stat potentiostat/galvanostat with electrochemical analysis software 270 using a threeelectrode set up comprising a glassy carbon working electrode, platinum wire auxiliary and saturated calomel reference electrode (SCE). $\mathrm{KCl}(0 \cdot 1 \mathrm{M})$ was used as a supporting electrolyte in DMF-Tris buffer medium $(1: 4 v / v)$. Room temperature magnetic susceptibility data were obtained with a model 300 Lewis coil-force magnetometer of George Associates Inc. (Berkeley, USA) make. Susceptibility data were corrected for diamagnetic contribution. ${ }^{45}$

\subsection{Synthesis of $\left[\mathrm{CuL}_{2}\right]\left(\mathrm{ClO}_{4}\right)_{2}(\mathbf{1})$}

The complex was prepared by reacting $0.5 \mathrm{~g}$ $(2.8 \mathrm{mmol})$ quantity of the Schiff base (L) with $0.2 \mathrm{~g}$ $(1.0 \mathrm{mmol})$ copper(II) acetate-hydrate, in $25 \mathrm{ml}$ methanol under stirring for $1 \mathrm{~h}$ at $25^{\circ} \mathrm{C}$. On completion of the reaction, a methanolic solution of sodium perchlorate $(0.3 \mathrm{~g}, 2.5 \mathrm{mmol})$ was added. The product was obtained as a dark green solid on slow concentration of the solution. The solid was isolated, washed with diethyl ether and finally dried in vacuum over $\mathrm{P}_{4} \mathrm{O}_{10}$ (yield: $78 \%$ ).

Analysis: Calc. for $\mathrm{C}_{18} \mathrm{H}_{24} \mathrm{~N}_{4} \mathrm{CuO}_{8} \mathrm{~S}_{2} \mathrm{Cl}_{2}$ : C, 34.72; H, 3.97; N, 9.03\%. Found: C, 34.86; H, 4.23; N, $8.85 \%$. IR (KBr phase, $\mathrm{cm}^{-1}$ ): $3484 b r, 3033 m, 1646 m$, $1600 s, 1569 w, 1475 w, 1473 m, 1445 m, 1375 w, 1302 m$, $1248 w, 1143 s, 1089 v s, 1021 w, 776 s, 636 s, 626 s$, $506 m, 418 m$ (br, broad; $w$, weak; $m$, medium; $s$, strong; $v s$, very strong). $\mu_{\text {eff }}=1.9 \mu_{B}$ at $300 \mathrm{~K} . \Lambda_{M}=156 \Omega^{-1}$ $\mathrm{cm}^{2} \mathrm{M}^{-1}$ at $25^{\circ} \mathrm{C}$ in DMF (complex $\left.=10^{-3} \mathrm{M}\right)$. The complex was found to be soluble in polar organic solvents and less soluble in water.

Caution! Perchlorate salts of metal complexes containing organic ligands are potentially explosive and small quantities should be taken at a time and handled with care.

\section{$2.4 X$ X-ray crystallographic procedures}

Single crystals of complex $\mathbf{1}$ were obtained by a diffusion technique in which an acetonitrile solution of the complex was layered with diethyl ether. The unit cell parameters and the intensity data of a crystal mounted on a glass fiber using epoxy cement were obtained using a Bruker SMART APEX CCD diffractometer, equipped with a fine focus $1.75 \mathrm{~kW}$ sealed tube Mo-K $\mathrm{K}_{\alpha} \mathrm{X}$-ray source, with increasing $\omega$ (width $0.3 \mathrm{deg}$ frame $^{-1}$ ) at a scan speed of $15 \mathrm{~s}$ frame $^{-1}$. The SMART software was used for data acquisition and the SAINT software for data abstraction. The data were corrected for absorption. ${ }^{46}$ Structure solution and refinement were done using SHELX system of programs. ${ }^{47}$ Hydrogen atoms were placed at their calculated positions and refined using a riding model. The non-hydrogen atoms were refined anisotropically. Crystal data and structure refinement parameters are given in table 1 . Perspective view of the complex was obtained using ORTEP. ${ }^{48}$ Detailed crystallographic data in the CIF format have been deposited with the Cambridge Crystallographic Data Center, CCDC No. 256343. Copies of this information may be obtained free of charge from the Director, CCDC, 12 Union Road, Cambridge CB2 1EZ, UK (Fax: +44-1223-336033; e-mail: deposit@ccdc.cam.ac.uk or www: http://www.ccdc/ cam.ac.uk).

\subsection{DNA binding experiments}

The experiments were carried out in Tris- $\mathrm{HCl}$ buffer (50 mM, pH 7.2) using a solution of calf thymus (CT) DNA which gave a ratio of UV absorbance at 260 and $280 \mathrm{~nm}$ in the range 1.8 to $1.9: 1$ indicating that the DNA is sufficiently free from protein. ${ }^{49}$ The CT DNA concentration was determined by absorption spectroscopy using the $\varepsilon$ value of $6600 \mathrm{M}^{-1} \mathrm{~cm}^{-1}$ at $260 \mathrm{~nm}^{50}$ Absorption titration experiments were carried out with a complex concentration of $50 \mu \mathrm{M}$, varying the CT DNA concentration from 80 to $720 \mu \mathrm{M}$. The intrinsic binding constant $K_{b}$ was determined from the [DNA] $/\left(\varepsilon_{a}-\varepsilon_{f}\right)$ vs. [DNA] plot using the relation: [DNA] $/\left(\varepsilon_{a}-\varepsilon_{f}\right)=[\mathrm{DNA}] /\left(\varepsilon_{b}-\varepsilon_{f}\right)+1 /$ $K_{b}\left(\varepsilon_{b}-\varepsilon_{f}\right)$, where [DNA] is the concentration of DNA. The absorption coefficients $\varepsilon_{a}, \varepsilon_{f}$ and $\varepsilon_{b}$ correspond to apparent absorption coefficient of the 
complex, extinction coefficient of the free copper complex and extinction coefficient of the copper(II) complex in the completely DNA bound form respectively.

Relative binding of the binary and ternary complexes was also studied by the fluorescence spectral method using ethidium bromide (EB) bound CT DNA solution. ${ }^{51}$ The fluorescence intensities at $600 \mathrm{~nm}$ (546 nm excitation) of EB with increase of the complex concentration were recorded at $25^{\circ} \mathrm{C}$. EB was non-emissive in the buffer medium due to the fluorescence-quenching effect of the solvent molecules. In presence of DNA, EB showed enhanced emission due to intercalative binding to DNA. Competitive binding of the copper complex to CT DNA resulted in the displacement of bound EB or quenching of its emission thus reducing the emission intensity. The apparent binding constant $\left(K_{\text {app }}\right)$ was calculated from the relation: $K_{E B}[\mathrm{~EB}]=K_{\text {app }}[$ complex $]$, where

Table 1. Selected crystallographic data and structure refinement for $\mathbf{1}$.

\begin{tabular}{|c|c|}
\hline Empirical formula & $\mathrm{C}_{18} \mathrm{H}_{24} \mathrm{Cl}_{2} \mathrm{CuN}_{4} \mathrm{O}_{8} \mathrm{~S}_{2}$ \\
\hline Formula weight $\left(\mathrm{g} \mathrm{mol}^{-1}\right)$ & $622 \cdot 97$ \\
\hline Temperature $(\mathrm{K})$ & 293(2) \\
\hline$\lambda(\AA)\left(\mathrm{Mo}-\mathrm{K}_{\alpha}\right)$ & $0 \cdot 71073$ \\
\hline Crystal system & Orthorhombic \\
\hline Space group & $P 2_{1} 2_{1} 2_{1}$ (no. 19) \\
\hline$a(\AA)$ & $9 \cdot 963(6)$ \\
\hline$b(\AA)$ & $14 \cdot 014(9)$ \\
\hline$c(\AA)$ & $18 \cdot 866(12)$ \\
\hline$a^{\prime}=\beta=\gamma\left({ }^{\circ}\right)$ & $90 \cdot 00$ \\
\hline$V\left(\AA^{3}\right)$ & $2634(3)$ \\
\hline Z & 4 \\
\hline$\rho_{\text {calc }}\left(\mathrm{g} \mathrm{cm}^{-3}\right)$ & $1 \cdot 571$ \\
\hline$\mu\left(\mathrm{Mo}-\mathrm{K}_{\alpha}\right)\left(\mathrm{m}^{-1}\right)$ & $12 \cdot 39$ \\
\hline Crystal size (mm) & $0.40 \times 0.19 \times 0.12$ \\
\hline$F(000)$ & 1276 \\
\hline $\begin{array}{l}\text { Theta range for data } \\
\text { collection }\end{array}$ & $1 \cdot 81$ to $26 \cdot 06^{\circ}$ \\
\hline Index ranges & $\begin{array}{l}-12 \leq h \leq 11,-17 \leq k \leq 17 \\
\quad-22 \leq l \leq 22\end{array}$ \\
\hline Refinement method & Full-matrix least-squares on $F^{2}$ \\
\hline Data/restraints/parameters & $5131 / 0 / 316$ \\
\hline Goodness-of-fit on $F^{2}$ & $1 \cdot 0301$ \\
\hline$R 1^{\mathrm{a}}[I>2 \sigma(I)]$ & $0 \cdot 0458$ \\
\hline$R 1$ [all data] & $0 \cdot 0504$ \\
\hline$w R 2^{\mathrm{b}}[I>2 \sigma(I)]$ & $0 \cdot 1295$ \\
\hline$w R 2$ [all data] & $0 \cdot 1348$ \\
\hline
\end{tabular}

$K_{E B}=1.0 \times 10^{7} \mathrm{M}^{-1}$ and the concentration of EB is $1 \cdot 3 \mu \mathrm{M}^{51}$

\subsection{DNA cleavage experiments}

The extent of cleavage of supercoiled (SC) pUC19 DNA $(0.8 \mu \mathrm{L}, 0.5 \mu \mathrm{g})$ to its nicked circular (NC) form was determined by agarose gel electrophoresis in Tris- $\mathrm{HCl}$ buffer $(50 \mathrm{mM}, \mathrm{pH} 7.2)$ containing $\mathrm{NaCl}(50 \mathrm{mM})$. In the cleavage reactions, the $33 \mu \mathrm{M}$ complexes in $18 \mu \mathrm{L}$ buffer were photo-irradiated using monochromatic UV or visible light. The samples were then incubated for $1 \mathrm{~h}$ at $37^{\circ} \mathrm{C}$ followed by addition to the loading buffer containing $25 \%$ bromophenol blue, $0.25 \%$ xylene cyanol, $30 \%$ glycerol $(3 \mu \mathrm{L})$ and finally loaded on $0.8 \%$ agarose gel containing $1.0 \mu \mathrm{g} / \mathrm{mL}$ ethidium bromide. Electrophoresis was carried out at $40 \mathrm{~V}$ for $2 \mathrm{~h}$ in Tris-acetate EDTA (TAE) buffer. Bands were visualized by UV light and photographed to determine the extent of DNA cleavage from the intensities of the bands using UVITEC Gel Documentation System. Due corrections were made for the trace of NC DNA present in the SC DNA sample and for the low affinity of EB binding to SC DNA in comparison to the NC form. ${ }^{44}$ The wavelengths used for the photo-induced DNA cleavage experiments were $365 \mathrm{~nm}(12 \mathrm{~W})$ and low powered CW He-Ne laser of $632.8 \mathrm{~nm}$ (ScientificaCook make, UK, $3 \mathrm{~mW}$ ) in the absence of any external additives. Control experiments were done for mechanistic investigations using different reagents that were added to DNA prior to the addition of the complex.

\section{Results and discussion}

\subsection{Synthesis and general aspects}

The binary complex $\left[\mathrm{CuL}_{2}\right]\left(\mathrm{ClO}_{4}\right)_{2}(\mathbf{1})$, prepared in high yield from the reaction of copper(II) acetate with the Schiff base and subsequently isolated as a perchlorate salt, is characterized from analytical and physicochemical data (table 2, scheme 1). The molecular structure of this complex is obtained from X-ray diffraction study. Two ternary complexes of formulation $[\mathrm{CuLB}]\left(\mathrm{ClO}_{4}\right)_{2}$ (B: phen, 2; dpq, 3) having phenanthroline bases are prepared using $\mathbf{1}$ as a precursor under in situ reaction conditions for DNA binding and cleavage studies. Complexes $\mathbf{2}$ and $\mathbf{3}$ having phen and dpq ligands are expected to show efficient DNA binding and cleavage properties, as 
Table 2. Physicochemical data on $\left[\mathrm{CuL}_{2}\right]\left(\mathrm{ClO}_{4}\right)_{2}(\mathbf{1})$ and $[\mathrm{CuLB}]\left(\mathrm{ClO}_{4}\right)_{2}(\mathrm{~B}=$ phen, 2; dpq, 3).

\begin{tabular}{|c|c|c|c|c|c|c|}
\hline \multirow[b]{2}{*}{ Complex } & \multicolumn{2}{|l|}{$\lambda_{\max }(\mathrm{nm})\left[\varepsilon\left(\mathrm{M}^{-1} \mathrm{~cm}^{-1}\right)\right]^{\mathrm{a}}$} & \multicolumn{2}{|c|}{$\mathrm{Cu}(\mathrm{II}) / \mathrm{Cu}(\mathrm{I})$ couple $^{\mathrm{b}}$} & \multirow[b]{2}{*}{$K_{\mathrm{b}}^{\mathrm{c}}\left(\mathrm{M}^{-1}\right)$} & \multirow[b]{2}{*}{$K_{\text {app }}{ }^{\mathrm{d}}\left(\mathrm{M}^{-1}\right)$} \\
\hline & CT band & $d-d$ band & $E_{1 / 2}(\mathrm{~V})\left[\Delta E_{p}(\mathrm{mV})\right]$ & $i_{p a} / i_{p c}$ & & \\
\hline 1 & $356(1720), 469(230)$ & $631(160)$ & $0 \cdot 15(150)$ & $0 \cdot 9$ & $3 \cdot 1 \times 10^{2}$ & $7 \cdot 0 \times 10^{3}$ \\
\hline 2 & $257(4660), 443(500)$ & $679(75)$ & $-0.05(75)$ & 0.7 & $1 \cdot 1 \times 10^{3}$ & $1.6 \times 10^{4}$ \\
\hline 3 & 256 (5930), $301(5880), 454(790)$ & $696(90)$ & $0 \cdot 046(180)$ & $0 \cdot 6$ & $5 \cdot 6 \times 10^{3}$ & $5.4 \times 10^{5}$ \\
\hline
\end{tabular}

${ }^{\mathrm{a}}$ In DMF. ${ }^{\mathrm{b}}$ In DMF-Tris buffer $(1: 4 v / v)$ using $0 \cdot 1 \mathrm{M} \mathrm{KCl}$ as supporting electrolyte. $E_{1 / 2}=0 \cdot 5\left(E_{p a}+E_{p c}\right), \Delta E_{p}=$ $E_{p a}-E_{p c}$, where $E_{p a}$ and $E_{p c}$ are anodic and cathodic peak potentials, respectively. Scan rate: $50 \mathrm{mVs}^{-1} . i_{p c}$ and $i_{p a}$ are cathodic and anodic peak currents respectively. ${ }^{\mathrm{c}}$ Intrinsic CT DNA binding constant by absorption spectroscopic method. ${ }^{\mathrm{d}}$ Apparent CT DNA binding constant from ethidium bromide displacement assay

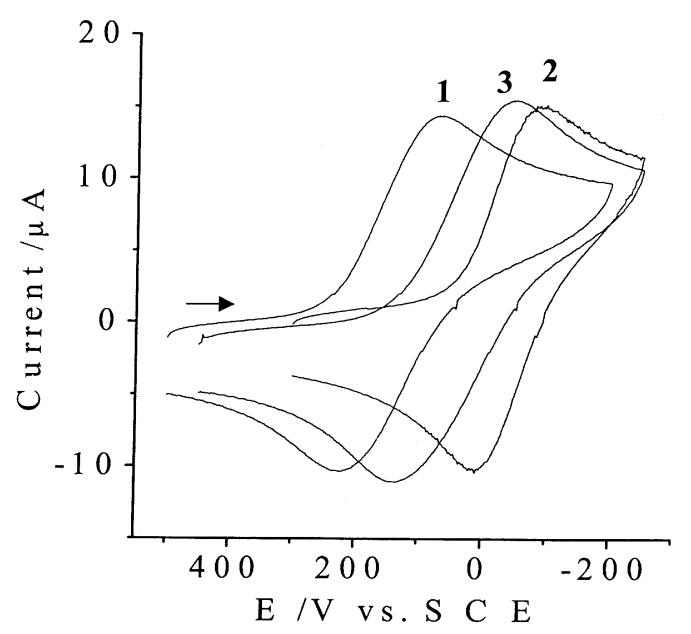

Figure 1. Cyclic voltammograms of 1-3 in DMF-Tris buffer $(1: 4, \mathrm{pH} 7 \cdot 2) / \mathrm{KCl}(0 \cdot 1 \mathrm{M})$ at a scan speed of $50 \mathrm{mVs}^{-1}$.

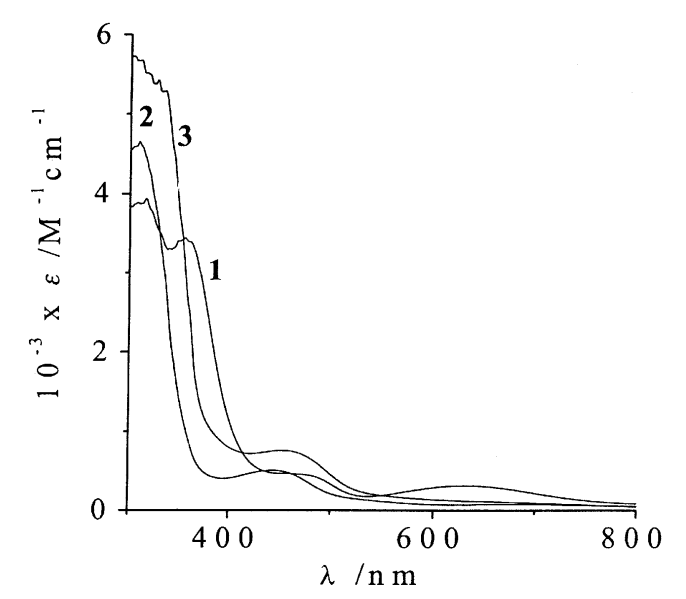

Figure 2. Electronic spectra of 1-3 in DMF.

the presence of such a planar heterocyclic base in transition metal complexes is known to enhance their DNA cleavage activity. ${ }^{1,2}$
Complexes 1-3 are redox active and display a quasi-reversible cyclic voltammetric response near $0 \cdot 0 \mathrm{~V}$ vs SCE in DMF-Tris buffer $(1: 4 v / v) / 0 \cdot 1 \mathrm{M}$ $\mathrm{KCl}$ (figure 1). The redox process is assignable to the $\mathrm{Cu}(\mathrm{II}) / \mathrm{Cu}(\mathrm{I})$ couple. The $E_{1 / 2}$ value varies in the order: $\mathbf{1}>\mathbf{3}>\mathbf{2}$. Complex $\mathbf{1}$ with two sulphur-containing Schiff-bases stabilises the copper(I) state more than the ternary structures. Again, the dpq complex $\mathbf{3}$ with extended aromatic ring stabilises the reduced state more than its phen analogue. We have not observed any formation of binary species $\left[\mathrm{CuB}_{2}\right]^{2+}$ during the generation of the ternary complexes in cyclic voltammetric studies when $1(1.0 \mathrm{mmol}$ in $5 \mathrm{ml}$ DMF-Tris buffer) is reacted with the heterocyclic base (B) in a 1:1 molar ratio. The electronic spectral data of the complexes in DMF show the presence of a $d-d$ band in the range 630 to $700 \mathrm{~nm}$ (figure 2). Complexes $\mathbf{2}$ and $\mathbf{3}$ display significantly lower energy $d-d$ bands than $\mathbf{1}$, possibly due to the structural differences between the binary and ternary complexes (scheme 1). The $d-d$ band being in the PDT window of 600-800 nm makes these complexes potential systems to explore the DNA cleavage activity on red-light irradiation. The complexes also exhibit charge transfer bands near $450 \mathrm{~nm}$ which could be assigned to the sulphur to copper(II) charge transfer LMCT band.

\subsection{Crystal structure}

Complex $\left[\mathrm{CuL}_{2}\right]\left(\mathrm{ClO}_{4}\right)_{2}$ (1) has been structurally characterized by single crystal X-ray crystallography. An ORTEP view of the cationic complex is shown in figure 3 and selected bond distances and angles are given in table 3 . The complex crystallizes in the orthorhombic space group $P 2{ }_{1} 2_{1} 2_{1}$ with four molecules in the unit cell. The crystallographic asymmetric unit consists of the mononuclear copper(II) complex 
Table 3. Selected bond lengths $(\AA)$ and angles $\left({ }^{\circ}\right)$ for $\mathbf{1}$.

\begin{tabular}{lclr}
\hline $\mathrm{Cu}(1)-\mathrm{N}(1)$ & $2 \cdot 143(4)$ & $\mathrm{N}(2)-\mathrm{Cu}(1)-\mathrm{S}(2)$ & $98 \cdot 88(11)$ \\
$\mathrm{Cu}(1)-\mathrm{N}(2)$ & $1 \cdot 968(3)$ & $\mathrm{N}(3)-\mathrm{Cu}(1)-\mathrm{N}(2)$ & $177 \cdot 37(14)$ \\
$\mathrm{Cu}(1)-\mathrm{N}(3)$ & $1 \cdot 953(3)$ & $\mathrm{N}(3)-\mathrm{Cu}(1)-\mathrm{N}(1)$ & $102 \cdot 86(14)$ \\
$\mathrm{Cu}(1)-\mathrm{N}(4)$ & $2 \cdot 158(4)$ & $\mathrm{N}(3)-\mathrm{Cu}(1)-\mathrm{N}(4)$ & $78 \cdot 74(15)$ \\
$\mathrm{Cu}(1)-\mathrm{S}(1)$ & $2 \cdot 599(2)$ & $\mathrm{N}(3)-\mathrm{Cu}(1)-\mathrm{S}(1)$ & $94 \cdot 47(11)$ \\
$\mathrm{Cu}(1)-\mathrm{S}(2)$ & $2 \cdot 7051(17)$ & $\mathrm{N}(3)-\mathrm{Cu}(1)-\mathrm{S}(2)$ & $81 \cdot 78(11)$ \\
$\mathrm{N}(1)-\mathrm{Cu}(1)-\mathrm{N}(4)$ & $102 \cdot 62(13)$ & $\mathrm{N}(4)-\mathrm{Cu}(1)-\mathrm{S}(1)$ & $95 \cdot 84(10)$ \\
$\mathrm{N}(1)-\mathrm{Cu}(1)-\mathrm{S}(1)$ & $156 \cdot 74(9)$ & $\mathrm{N}(4)-\mathrm{Cu}(1)-\mathrm{S}(2)$ & $158 \cdot 13(10)$ \\
$\mathrm{N}(1)-\mathrm{Cu}(1)-\mathrm{S}(2)$ & $91 \cdot 27(9)$ & $\mathrm{S}(1)-\mathrm{Cu}(1)-\mathrm{S}(2)$ & $75 \cdot 82(5)$ \\
$\mathrm{N}(2)-\mathrm{Cu}(1)-\mathrm{N}(1)$ & $79 \cdot 69(13)$ & & \\
$\mathrm{N}(2)-\mathrm{Cu}(1)-\mathrm{N}(4)$ & $100 \cdot 16(14)$ & & \\
$\mathrm{N}(2)-\mathrm{Cu}(1)-\mathrm{S}(1)$ & $83 \cdot 25(11)$ & & \\
\hline
\end{tabular}

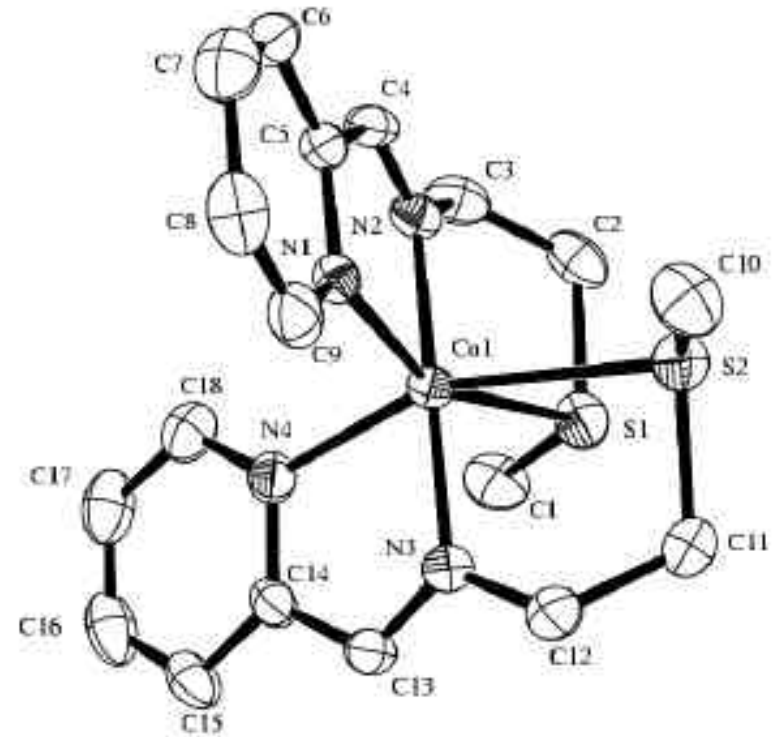

Figure 3. ORTEP diagram of the cationic complex in $\mathbf{1}$ showing atom-numbering scheme and thermal ellipsoids at $50 \%$ probability level.

and two lattice perchlorate anions. In the binary structure, the copper atom is bonded to two Schiffbase ligands each showing tridentate chelating $\mathrm{N}_{2} \mathrm{~S}$ binding mode giving a six-coordinate meridional pseudo-octahedral structure. The thiomethyl moieties are $c$ is to each other. The $\mathrm{Cu}-\mathrm{S}$ bonds of 2.6 and $2.7 \AA$ are unusually long when compared to known ternary copper(II) complexes having similar metalbound thiomethyl moiety bound at the basal plane like in structure (I) (scheme 2). ${ }^{29,31,52}$ This bond is of particular importance as a shorter $\mathrm{Cu}-\mathrm{S}$ bond length is expected to show enhanced photosensitization effect leading to higher metal-assisted DNA photocleavage activity. It is likely that in presence of strong $\mathrm{Cu}-\mathrm{N}$ (pyridine) and $\mathrm{Cu}-\mathrm{N}$ (imine) bonds of $\approx 2.15$ and
$1.96 \AA$, the $\mathrm{Cu}-\mathrm{S}$ bond becomes long due to steric constraints imposed by two 5-membered rings of the $\{\mathrm{CuL}\}$ unit. In comparison, the presence of sixmember rings in structures (I) and (II) of the $\{\mathrm{Cu}$ (salicylaldimine moiety)\} reduces the steric strain considerably in (I) and (II) (scheme 2). The long $\mathrm{Cu}-\mathrm{S}$ bond of $\sim 2.7 \AA$ in (II) is due to the presence of sulphur at the elongated axial site of the five coordinate structure. In $\mathbf{1}$, the imine nitrogen atoms are essentially trans to each other. The $\mathrm{N}(1)-\mathrm{Cu}(1)-\mathrm{S}(1)$ and $\mathrm{N}(4)-\mathrm{Cu}(1)-\mathrm{S}(2)$ angles of $\approx 157^{\circ}$ deviate significantly from the trans geometrical arrangement. This is again due to the steric constraints of the fivemembered chelate rings. The structural features of $\mathbf{1}$ suggest this complex to be sterically unstable and we are able to generate the ternary complexes $\mathbf{2}$ and $\mathbf{3}$ on stoichiometric reactions using $\mathrm{N}, \mathrm{N}$-donor heterocyclic bases phen and dpq.

\subsection{DNA binding property}

Absorption and fluorescence spectral techniques have been used to determine the relative binding propensity of the complexes to CT DNA (table 2, figure 4). The intrinsic binding constant values, obtained by absorption spectral method, vary as: $\mathbf{3}>\mathbf{2}>\mathbf{1}$. The dpq complex with its extended aromatic quinoxaline ring shows efficient DNA-binding ability. The phen complex is relatively a poor binder to DNA. Earlier studies on bis-phen or bis-dpq copper complexes have shown that the complexes bind DNA in the minor groove..$^{30,40-42} \mathrm{~A}$ similar mode of binding is expected for complexes $\mathbf{2}$ and $\mathbf{3}$. Complex $\mathbf{1}$ shows poor DNA binding propensity due to the absence of any planar ligand moieties for intercalative and/or groove binding to DNA. The dicationic complexes are, in addition, expected to have electrostatic inter- 

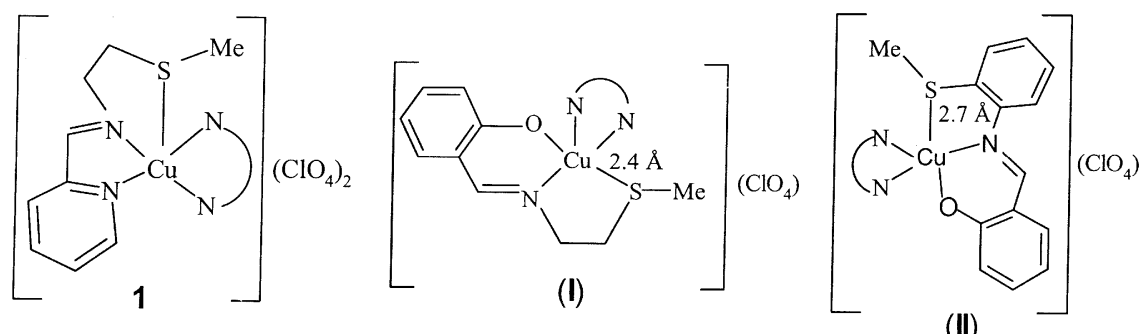

Scheme 2. A comparison of the structural features in $\mathbf{1}$ and reported ternary copper(II) complexes (I) and (II) having similar metal-bound thiomethyl moiety.

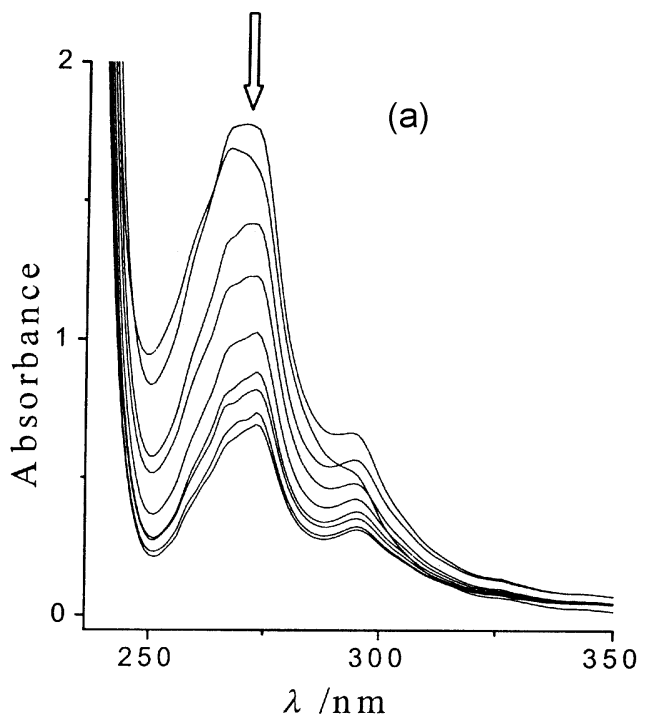

(b)
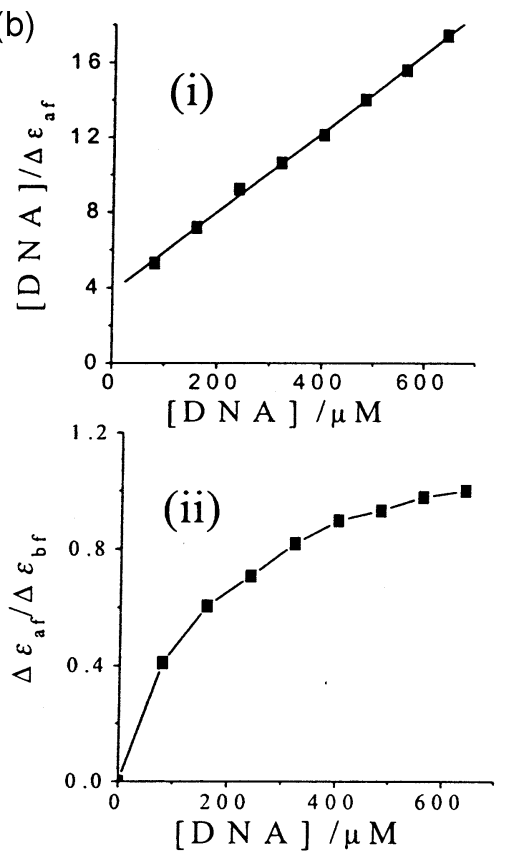

Figure 4. (a) Absorption spectral changes on addition of CT DNA to the solution of $\mathbf{3}$ (shown by arrow). (b) Plots of [DNA] $/\left(\Delta \varepsilon_{a f}\right)$ vs [DNA] (i) and $\Delta \varepsilon_{a f} / \Delta \varepsilon_{b f}$ vs [DNA] (ii), where $\Delta \varepsilon_{a f}=\left(\varepsilon_{a}-\varepsilon_{f}\right)$ and $\Delta \varepsilon_{b f}=\left(\varepsilon_{b}-\varepsilon_{f}\right)$. action with the double-stranded DNA. The apparent binding constant values of the complexes, obtained from ethidium bromide displacement assay by fluorescence spectral method, show similar binding order as observed from the absorption spectral studies.

\subsection{DNA cleavage activity}

The oxidative DNA cleavage activity of the complexes was studied by gel electrophoresis using supercoiled (SC) pUC19 DNA $(0.5 \mu \mathrm{g})$ in Tris- $\mathrm{HCl}$ buffer $(\mathrm{pH}, 7 \cdot 2)$. Selected DNA cleavage data are given in table 4 and the gel diagrams are shown in figure 5. The complexes 1-3 (33 $\mu \mathrm{M}$ in $18 \mu$ l volume) show 46, 68 and $71 \%$ cleavage of the SC DNA respectively, on $1 \mathrm{~h}$ exposure at $365 \mathrm{~nm}$. The greater cleavage efficiency of the ternary complexes compared to that of the binary complex $\mathbf{1}$ is due to their efficient DNA-binding ability. Control experiments using Schiff base or the dpq ligand alone does not show any significant cleavage of SC DNA even on longer exposure time. The results indicate the important role of metal in these photo-induced DNA cleavage reactions. The complexes show the presence of a charge-transfer band near $450 \mathrm{~nm}$. It is likely that the photo-cleavage at $365 \mathrm{~nm}$ involves photoexcitation of the charge-transfer band leading to the formation of an excited singlet state that through the triplet state activates molecular oxygen to form reactive singlet oxygen species. Control experiments show that the singlet oxygen quencher sodium azide significantly inhibits the cleavage reaction, while the hydroxyl radical scavenger DMSO has no apparent effect on the cleavage process. The formation of singlet oxygen is further supported by the enhancement of percent SC DNA cleavage in $\mathrm{D}_{2} \mathrm{O}$ solvent in which singlet oxygen is known to have longer triplet state life time. ${ }^{53}$ The oxidative DNA cleavage by singlet oxygen is likely to proceed via oxidation of guanine nucleobase. ${ }^{2,54}$ The cleavage activity of $\mathbf{2}$ 
Table 4. Selected DNA (SC pUC19 DNA, 0.5 $\mu \mathrm{g}$ ) cleavage data ${ }^{\mathrm{a}}$ of complexes $\mathbf{1}-\mathbf{3}$ in Tris-buffer ( $\mathrm{pH} \mathrm{7 \cdot 2)}$.

\begin{tabular}{lccccc}
\hline Reaction conditions & $\lambda(\mathrm{nm})$ & $t(\mathrm{~h})$ & [Complex] $(\mu \mathrm{M})$ & Form-I $(\%)$ & Form-II $(\%)$ \\
\hline DNA control & 365 & $1 \cdot 5$ & - & 93 & 7 \\
DNA + 1 & 365 & $1 \cdot 0$ & 33 & 54 & 46 \\
DNA + 2 & 365 & $1 \cdot 0$ & 33 & 32 & 68 \\
DNA + 3 & Dark & $1 \cdot 5$ & - & 91 & 9 \\
DNA + 3 & 365 & $1 \cdot 0$ & 33 & 29 & 71 \\
DNA + 3 in $\mathrm{D}_{2} \mathrm{O}(14 \mu \mathrm{L})$ & 365 & $1 \cdot 0$ & 33 & 10 & 90 \\
DNA + NaN $(38 \mu \mathrm{M})+\mathbf{3}$ & 365 & $1 \cdot 0$ & 33 & 89 & 11 \\
DNA + DMSO $(4 \mu \mathrm{L})+\mathbf{3}$ & 365 & $1 \cdot 0$ & 33 & 34 & 66 \\
DNA + L $(66 \mu \mathrm{M})$ & 356 & $1 \cdot 0$ & - & 92 & 8 \\
DNA + dpq $(33 \mu \mathrm{M})$ & 365 & $1 \cdot 5$ & - & 88 & 12 \\
DNA control & $632 \cdot 8$ & $1 \cdot 0$ & - & 98 & 2 \\
DNA + 1 & 632.8 & $1 \cdot 0$ & 33 & 95 & 3 \\
DNA + 2 & 632.8 & $1 \cdot 0$ & 33 & 77 & 5 \\
DNA + 3 & 632.8 & $1 \cdot 0$ & 33 & 23 \\
\hline
\end{tabular}

${ }^{\mathrm{a}} \lambda$, excitation wavelength; $t$, exposure time; form-I and form-II are SC and NC forms of DNA respectively

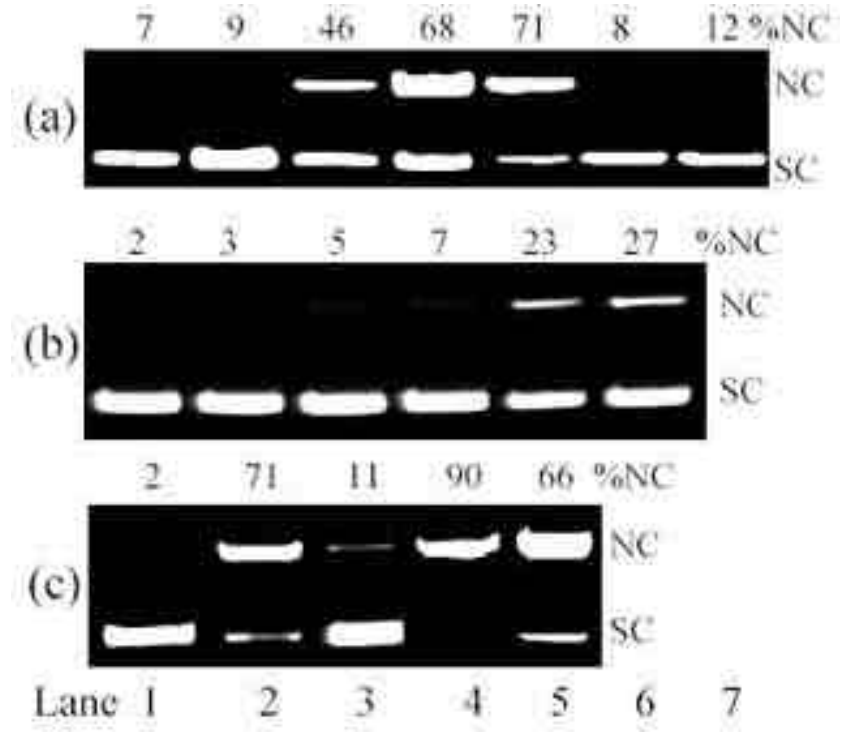

Figure 5. (a) Gel diagram showing the photo-cleavage of SC pUC19 DNA $(0.5 \mu \mathrm{g})$ by 1-3 $(33 \mu \mathrm{M})$ in DMFTris buffer medium on $1 \mathrm{~h}$ exposure at $365 \mathrm{~nm}$. Complexes $\mathbf{2}$ and $\mathbf{3}$ are in situ generated by reacting $\mathbf{1}$ with the bases phen or dpq in a $1: 1$ molar ratio. Lane 1 , DNA control (1 h); lane 2, DNA + 3 (in dark); lane 3, $\mathrm{DNA}+1$; lane 4, DNA + 2; lane 5, DNA + 3; lane 6, $\mathrm{DNA}+\mathrm{L}(66 \mu \mathrm{M})$; lane $7, \mathrm{DNA}+\mathrm{dpq}(33 \mu \mathrm{M})$. (b) Gel diagram showing the photo-cleavage of SC pUC19 DNA $(0.5 \mu \mathrm{g})$ by $\mathbf{1}-\mathbf{3}(17 \mu \mathrm{M})$ in DMF-Tris buffer medium on irradiation with $\mathrm{CW} \mathrm{He}-\mathrm{Ne}$ laser of $632.8 \mathrm{~nm}$ wavelength. Lane 1, DNA control $(1 \mathrm{~h})$; lane 2, DNA + 1 $(1 \mathrm{~h})$; lane 3, DNA + 2 (1 h); lane 4, DNA + 2 (2 h); lane 5 , DNA + $3(1 \mathrm{~h})$; lane 6 , DNA +3 (2 h). (c) Gel electrophoresis diagram of the control experiments using SC DNA $(0.5 \mu \mathrm{g}), 3(33 \mu \mathrm{M})$, and other additives at $365 \mathrm{~nm}$ for an exposure time of $1 \mathrm{~h}$. Lane 1, DNA Control; lane 2, DNA + 3; lane 3, DNA + $\mathrm{NaN}_{3}(38 \mu \mathrm{M})+3$; lane 4, $\mathrm{DNA}+\mathrm{D}_{2} \mathrm{O}(14 \mu \mathrm{L})+\mathbf{3}$; lane 5 , DNA + DMSO $(4 \mu \mathrm{L})+3$. and $\mathbf{3}$ at $365 \mathrm{~nm}$ is essentially the same although $\mathbf{3}$ is expected to show significantly higher cleavage activity than 2 based on its greater DNA binding propensity. This could be due to the weak nature of the visible $\sim 450 \mathrm{~nm}$ band.

We have also studied the photo-induced DNA cleavage activity of the complexes using a CW He$\mathrm{Ne}$ laser at $632.8 \mathrm{~nm}$. This wavelength is ideally suited as complex 1 has a $d-d$ band at $631 \mathrm{~nm}$ and the anticancer drug Photofrin ${ }^{\circledR}$ is known to be active at $630 \mathrm{~nm}$. While complexes $\mathbf{1}$ and $\mathbf{2}$ are cleavageinactive at $632.8 \mathrm{~nm}$, the dpq complex $\mathbf{3}$ showing $23 \%$ of DNA cleavage is less active in comparison to its analogous ternary copper(II) complexes having short $\mathrm{Cu}-\mathrm{S}$ bond lengths (scheme 2). ${ }^{29,31}$ The red light-induced photocleavage of $\mathbf{3}$ is, however, similar to that observed for the ternary species (II) with a $\mathrm{Cu}-\mathrm{S}$ bond length of $\sim 2.7 \AA$. The results indicate the necessity of a strong $\mathrm{Cu}-\mathrm{S}$ bond in the ternary structure along with the absence of any $\pi$-conjugation between the thiomethyl and imine moieties for observing efficient red light-induced DNA cleavage.

\section{Conclusion}

A new binary six-coordinate copper(II) complex containing tridentate Schiff-base ligand with $\mathrm{CuN}_{4} \mathrm{~S}_{2}$ coordination in meridional geometry is prepared and structurally characterized by X-ray crystallography. The complex shows cis disposition of two thiomethyl moieties having significantly long $\mathrm{Cu}-\mathrm{S}$ distances. Complex $\mathbf{1}$ is found to be a poor binder and cleaver of DNA in the absence of any planar ligand 
moiety needed for intercalative and/or groove binding of DNA. Using complex $\mathbf{1}$ as a precursor, two new ternary copper(II) complexes having the sulphurcontaining Schiff-base as photosensitizer and phen or dpq as DNA binder are generated under in situ reaction conditions. The ternary complexes display significantly enhanced DNA binding and photoinduced DNA cleavage activity in comparison to $\mathbf{1}$ owing to the formation of singlet oxygen as the reactive species in a type-II process. The steric constraints imposed by two five-membered chelate rings in the $\{\mathrm{CuL}\}$ moiety results in significant lengthening of the $\mathrm{Cu}-\mathrm{S}$ bond. A weak $\mathrm{Cu}-\mathrm{S}$ bond considerably reduces the photosensitizing effect of the Schiff-base ligand. The results show the importance of the $\mathrm{Cu}-\mathrm{S}$ bond length on the photo-induced DNA cleavage activity and its significance in designing non-porphyrinic transition metal complexes for PDT applications.

\section{Acknowledgements}

We thank the Council of Scientific and Industrial Research (CSIR), New Delhi, and the Department of Science and Technology (DST), Government of India, for financial support. AKP thanks the CSIR for a research fellowship. We also thank the DST for the CCD diffractometer facility; Alexander von Humboldt Foundation, Germany, for donation of an electroanalytical system; and Prof P K Das of our department for the laser facility.

\section{References}

1. Sigman D S, Mazumdar A and Perrin D M 1993 Chem. Rev. 932295

2. Erkkila K E, Odom D T and Barton J K 1999 Chem. Rev. 992777

3. Pogozelski W K and Tullius T D 1998 Chem. Rev. 98 1089

4. Burrows C J and Muller J G 1998 Chem. Rev. 981109

5. Armitage B 1998 Chem. Rev. 981171

6. Pratviel G, Bernadou J and Meunier B 1998 Adv. Inorg. Chem. $\mathbf{4 5} 251$

7. Meunier B 1992 Chem. Rev. 921411

8. Pratviel G, Bernadou J and Meunier B 1995 Angew. Chem., Int. Ed. Engl. 34746

9. McMillin D R and McNett K M 1998 Chem. Rev. 98 1201

10. Lippard S J 1999 Chem. Rev. 992467

11. Hegg E L and Burstyn J N 1998 Coord. Chem. Rev. 173133

12. Reedijk J 2001 J. Inorg. Biochem. 8689
13. Wolkenberg S E and D L Boger 2002 Chem. Rev. 1022477

14. Sreedhara A and Cowan J A 2001 J. Biol. Inorg. Chem. 6337

15. Ali H and VanLier J E 1999 Chem. Rev. 992379

16. Bonnett R 1995 Chem. Soc. Rev. 2419

17. Sessler M C, Hemmi G, Mody T D, Murai T, Burrel A and Young S W 1994 Acc. Chem. Res. 2743

18. Ackroyd R, Kelty C, Brown N and Reed M 2001 Photochem. Photobiol. 74656

19. De Rosa M C and Crutchley R J 2002 Coord. Chem. Rev. 233/4 351

20. Sternberg E D, Dolphin D and Brückner C 1998 Tetrahedron 544151

21. Delaney S, Pascaly M, Bhattacharya P K, Han K and Barton J K 2002 Inorg. Chem. 411966

22. Hastings C A and Barton J K 1999 Biochemistry 38 10042

23. Angeles-Boza A M, Bradley P M, Fu P K-L, Wicke S E, Bacsa J, Dunbar K R and Turro C 2004 Inorg. Chem. 438510

24. Ambroise A and Maiya B G 2000 Inorg. Chem. 39 4264

25. Sastri C V, Eswaramoorthy D, Giribabu L and Maiya B G 2003 J. Inorg. Biochem. 94138

26. Hergueta-Bravo A, Jimenez-Hernandez M E, Montero F, Oliveros E and Orellana G 2002 J. Phys. Chem. B 1064010

27. Eppley H J, Lato S M, Ellington A D and Zalesky J M 1999 Chem. Commun. 2405

28. Dhar S and Chakravarty A R 2003 Inorg. Chem. 42 2483

29. Dhar S, Senapati D, Das P K, Chattopadhyay P, Nethaji M and Chakravarty A R $2003 \mathrm{~J}$. Am. Chem. Soc. 12512118

30. Dhar S, Senapati D, Reddy P A N, Das P K and Chakravarty A R 2003 Chem. Commun. 2452

31. Reddy P A N, Santra B K, Nethaji M and Chakravarty A R 2004 J. Inorg. Biochem. 98377

32. Thomas A M, Nethaji M and Chakravarty A R 2004 J. Inorg. Biochem. 981087

33. Thomas A M, Naik A D, Nethaji M and Chakravarty A R 2004 Inorg. Chim. Acta 357/8 2315

34. Thomas A M, Naik A D, Nethaji M and Chakravarty A R 2004 Indian J. Chem. A43 691

35. Patra A K, Dhar S, Nethaji M and Chakravarty A R 2003 Chem. Commun. 1562

36. Gupta T, Dhar S, Nethaji M and Chakravarty A R 2004 Dalton Trans. 1896

37. Qian X, Huang T-B, Wei D-Z, Zhu D-H, Fan M-C and Yao W 2000 J. Chem. Soc., Perkin Trans. 2715

38. Jakobs A and Piette J 1994 J. Photochem. Photobiol. B22 9

39. Jakobs A and Piette J 1995 J. Med. Chem. 38869

40. Santra B K, Reddy P A N, Neelakanta G, Mahadevan S, Nethaji M and Chakravarty A R 2002 J. Inorg. Biochem. 89191

41. Zelenko O, Gallagher J and Sigman D S 1997 Angew. Chem., Int. Ed. Engl. 362776 
42. Veal J M, Merchant K and Rill R L 1991 Nucleic Acids Res. 193383

43. Toshima K, Takano R, Ozawa $\mathrm{T}$ and Matsumura $\mathrm{S}$ 2002 Chem. Commun. 212

44. Bernadou J, Pratviel G, Bennis F, Girardet M and Meunier B 1989 Biochemistry 287268

45. Kahn O 1993 Molecular magnetism (Weinheim, Germany: VCH)

46. Sheldrick G M 2001 SADABS, Version 2, MultiScan Absorption Correction Program, Universität of Göttingen, Göttingen, Germany

47. Sheldrick G M 1997 SHELX-97, A Computer Program for Crystal Structure Solution and Refinement, Universität Göttingen, Göttingen, Germany
48. Johnson C K 1976 ORTEP III Report ORNL-5138, Oak Ridge National Laboratory: Oak Ridge, Tennessee, USA

49. Marmur J 1961 J. Mol. Biol. 3208

50. Reichmann M E, Rice S A, Thomas C A and Doty P 1954 J. Am. Chem. Soc. 763047

51. Lee M, Rhodes A L, Wyatt M D, Forrow S and Hartley 1993 Biochemistry 324237

52. Santra B K, Reddy P A N, Nethaji M and Chakravarty A R 2001 J. Chem. Soc., Dalton Trans. 3553

53. Khan A U 1976 J. Phys. Chem. 802219

54. Croke D T, Perrouault L, Sari M A, Battioni J P, Mansuy D, Helene C and Le Doan T 1993 J. Photochem. Photobiol. B18 41 